\title{
Pengaruh Pengetahuan Akuntansi dan Kepribadian Wirausaha Terhadap Kinerja Manajerial Pada Perusahaan Manufaktur Di Provinsi Sumatra Barat
}

\author{
Rizka Mukhlisiah ${ }^{1}$, Ethika $^{2}$, Resti Yulistia $\mathbf{M}^{3}$ \\ Dosen Akuntansi Universitas Raharja ${ }^{1}$, Dosen Universitas Bung Hatta ${ }^{2}$, Dosen Universitas \\ Bung Hatta ${ }^{3}$ \\ rizka.mukhlisiah@ raharja.info ${ }^{l}$,
}

This study aims to determine the effect of accounting knowledge and entrepreneurial personality on managerial performance in manufacturing companies located in the province of West Sumatra. List of manufacturing companies was obtained from Badan Pusat Statistik (BPS) Padang.

Data was collected by survey method. Data obtained using a questionnaire distributed to managers. For the selection of samples was done by purposive sampling method. Analysis using testing through test the validity and reliability of the data, the classical assumption test (test for normality, multicollinearity), multiple linear regression hypothesis test.

The study concluded the effect of accounting knowledge and entrepreneurial personality simultaneously influence on managerial performance, but partially entrepreneurial personality has no effect on managerial performance.

Keywords: Accounting Knowledge, Entrepreneurial Personality, Managerial Performance

\section{Pendahuluan}

Kegiatan bisnis dan persaingan
bisnis yang semakin meningkat
menyebabkan perusahaan untuk bersaing
di persaingan global. Manajer perusahaan
juga mempunyai tujuan untuk
meningkatkan nilai perusahaan melalui
implementasi keputusan keuangan agar
organisasi mampu bersaing dalam era
perubahan saat ini. Oleh sebab itu
pelaksanaan yang dilakukan harus dengan
hati-hati dan tepat, mengingat setiap
keputusan akuntansi yang akan diambil

mempengaruhi keputusan keuangan lainnya dan akan berdampak terhadap pencapaian tujuan perusahaan.

Persaingan dunia yang semakin ketat membuat perusahaan harus dapat menghimpun konsumen sebanyak mungkin agar dapat bertahan, termasuk persaingan dalam perusahaan manufaktur. Tetapi perusahaan manufaktur tersebut juga harus memperhatikan kualitas yang dihasilkan dari masing-masing karyawannya, terutama kualitas para manajer. Jika kualitas karja ditingkatkan, 
maka produk yang dihasilkan akan berkualitas tinggi.

Akuntansi terbentuk dari interaksi sosial dan dipengaruhi oleh lingkungan sehingga definisi akuntansipun berkembang seiring dengan perubahanperubahan kondisi masyarakat di mana dia berada. Ilmu akuntansi, dengan demikian mengikuti dan merespon perkembngan perubahan yang terjadi di masyarakat dengan menyediakan informasi yang sesuai dengan perubahaan tersebut. Perkembangan dan persaiangan dunia bisnis yang semakin cepat dan tajam membuat entitas bisnis harus semakin jeli dan dapat mengambil keputusan-keputusan strategis yang berkaitan dengan kelangsungan hidup entitas tersebut. Kebutuhan ini menuntut sumbangan yang lebih dari akuntansi (Ernawati, 2011).

Persaingan dunia yang semakin ketat membuat perusahaan harus dapat menghimpun konsumen sebanyak mungkin agar dapat bertahan, termasuk persaingan dalam perusahaan manufaktur. Tetapi perusahaan manufaktur tersebut juga harus memperhatikan kualitas yang dihasilkan dari masing-masing karyawannya, terutama kualitas para manajer. Jika kualitas karja ditingkatkan, maka produk yang dihasilkan akan berkualitas tinggi.
Sabri (2013) menyebutkan kewirausahaan (Entrepreneurship) merupakan persoalan paling penting didalam perekonomian suatu bangsa yang sedang membangun seperti Indonesia. Persoalan yang kita hadapi saat ini adalah rendahnya minat masyarakat untuk menjadi wirausaha. 4,676 juta orang $(0,8$ persen) penduduk Indonesia memilih menjadi wirausaha. Kondisi saat ini masih sangat jauh jika dibandingkan dengan Negara-negara lain seperti Singapura, Cina dan Amerika Serikat. Kelompok kewirausahaan (Entrepreneurship) yang dikenal sebagai modal manusia memiliki peran dalam memajukan perekonomian. Kemajuan bangsa Jepang dan Cina misalnya dimotori oleh wirausahawan. Gelombang usahawanlah yang telah merubah wajah negara-negara tersebut menjadi Negara dengan tingkat capaian ekonomi tertinggi di dunia. Indonesia perlu "mewarisi" pengalaman Hongkong atau Taiwan yang telah berhasil melakukan revolusi kewirausahaan hingga akhirnya dapat meningkatkan pendapatan nasional dan memperkuat dinamika ekonomi secara keseluruhan.

Eoh (2009) dalam Ernawati (2011) menyatakan dinamika kehidupan bisnis masakini dipicu oleh tiga faktor (baca: 3P); (1) Pelanggan, yang tuntutan kebutuhannya semakin kompleks; 
Persaiangan, yang gojolaknya makin ketat dan meluas secara mendunia; (3) Perubahan, lingkungan bisnis yang serba cepat menimbulkan ketidakpastian dan sulit diprediksi. Berbagai tuntutan itu dapat dikategorikan atas dua segi; (1) Tantangan eksternal berkenaan dengan tuntutan lingkungan bisnis yang memicu perusahaan meningkatkan daya adaptasi eksternal agar dapat bertahan hidup dan daya inovasi agar selalu relevan dan unggul; (2) Tantangan internal berkenaan dengan kemampuan memanaj integrasi internal yang kohesif dan tangguh serta terciptanya suasana kerja yang kondusif bagi manajer. Hal ini tidak berlaku pada perusahaan jasa atau dagang saja tetapi juga manufaktur. Pengetahuan akuntansi dan kepribadian wirausaha yang dimiliki manajer untuk mengambil keputusan yang efektif dan efesien agar mencapai tujuan organisasi.

Untuk menjadi manajer yang profesional, manajer membutuhkan keahlian dari pendidikan dan pengalaman berorganisasi, agar mampu menggambil keputusan terhadap kemajuan organisasi yang dipimpinnya. Kinerja yang bermakna bukan hanya menghasilkan kinerja yang tinggi,tetapi juga kinerja yang menyebabkan seseorang mempunyai arti dalam kehidupan kerjanya sehingga dihormati dan menjadi panutan pihak lain.
Kepribadian wirausaha adalah seluruh konsep, pengetahuan yang abstrak untuk memperoleh sumber daya yang bernilai rendah, secara eksplisit, dan bagai mana menyebarkan sumber daya (Siregar, 2009). Kasali (2003) dalam Harisman (2012) menyatakan penggunaan spirit kewirausahaan di Indonesia menjadi suatu kebutuhan yang mendesak karena modal sosial bangsa dan perekonomian Indonesia telah semakin terpuruk pasca krisis moneter pada akhir tahun 90-an.

Penelitian ini merupakan replikasi dari penelitian Siregar (2009) tentang pengaruh pengetahuan akuntansi dan kepribadian wirausaha terhadap kinerja manajerial pada perusahaan jasa di kota Medan. Berbeda dengan penelitian Siregar (2009), penelitian ini lebih memfokuskan pada perusahaan manufaktur di Provinsi Sumatra Barat. Penelitian ini menggambil sampel perusahaan-perusahaan manufaktur yang terdapat di Provinsi Sumatra Barat dengan menggunakan metode survey yang menggunakan kuesioner.

\section{Teori dan Pengembangan Hipotesis}

\subsection{Teori Harapan (Expenctancy Theory)}

Hudayati (2002) menyebutkan bahwa dalam expenctancy theory motivasi individu ditentukan oleh expentancles dan valences. 
Expentancles adalah kenyakinan tentang kemungkinan bahwa prilaku tertentu (seperti misalnya bekerja lebih keras) akan menimbulkan hasil tertentu (seperti misalnya kenaikan gaji. Valences berarti nilai yang diberikan individu atas outcome (hasil) atau rewards yang akan diterima.

\subsection{Teori Goal (Goal Theory)}

Teori ini mula-mula dikembangkan oleh Edwin A. Locke (1968). Teori ini mengemukakan bahwa perilaku seseorang ditentukan oleh dua cognitions yaitu Value dan intensius (tujuan). Yang dimaksud dengan Value adalah apa yang dihargai seseorang sebagai upanya mendapatkan kemakmuran/welfare. Orang telah menentukan goal atas perilakunya dimasa depan dan goal tersebut akan mempengaruhi perilaku yang sesungguhnya. Teori ini juga menyatakan bahwa perilaku individu diatur oleh ide (pemikiran) niat seseorang. Sasaran dapat dipandang sebagai tujuan/tingkat kinerja yang ingin dicapai oleh individu. Jika seseorang individu komit dengan sasaran tertentu, maka hal ini akan mempengaruhi tindakannya dan mempengaruhi kosekuensi kerja.

\subsection{Pengaruh Pengetahuan Akuntansi Terhadap Kinerja Manajerial}

Pengetahuan akuntansi dapat didefinisikan sebagai seperangkat ilmu tentang informasi yang menghasilkan laporan keuangan kepada pihak yang berkepentingan mengenai aktivitas ekonomi dan kondisi perusahaan (Niswonger, 1996) dalam Siregar (2009).

Argumentasi pengaruh pengetahuan akuntansi terhadap kinerja manajeril diantaranya adalah Siregar (2009) meneliti tentang pengaruh pengetahuan akuntansi terhadap kinerja manajerial pada perusahaan jasa di kota medan. Hasil penelitian menunjukan bahwa pengetahuan akuntansi sangat berpengaruh terhadap kinerja manajerial dalam suatu perusahaan. Apabila seorang manajer perusahaan memiliki pengetahuan akuntansi yang memadai atau diatas rata-rata, yang diukur berdasarkan kemampuan seseorang manajer dalam membuat perencanaan maka prospek mereka dalam menjalankan perusahaan akan berjalan dengan baik seiring pula dengan ilmu yang dimilikinya. Ernawati (2011) meneliti tentang analisis pengetahuan akuntansi terhadap kinerja manajerial pada perusahaan jasa. 
Hasil menunjukan bahwa pengetahuan akuntansi berpengaruh terhadap kinerja manajerial. Sinta (2011) juga berpendapat bahwa pengetahuan akuntansi berpengaruh terhadap kinerja menajerial.

Pengujian terhadap pengaruh pengetahuan akuntansi terhadap kinerja manajerial juga pernah dilakukan oleh Siregar (2013) yang meneliti tentang pengaruh pengetahuan akuntansi terhadap kinerja manajerial pada usaha kecil menengah di Kabupaten Sleman Yogyakarta. Hasil penelitian tersebut menyatakan pengetahuan akuntansi berpengaruh terhadap kinerja manajerial pada usaha kecil menengah. Sebelumnya Siregar dan Erlina (2007) juga telah meneliti tentang pengaruh pengetahuan akuntansi terhadap kinerja manajerial pada perusahaan jasa di kota Medan. Hasil tersebut menunjukkan pengetahuan akuntansi berpengaruh terhadap kinerja manajerial pada perusahaan jasa di kota Medan.

Pendapat tersebut berbeda dengan Harisman (2012) yang meneliti tentang pengaruh pengetahuan akuntansi terhadap kinjera manajerial pada perusahaan jasa di kota Padang. Hasil penelitian tersebut menunjukkan pengetahuan akuntansi tidak berpengaruh terhadap kinerja manajerial pada perusahaan jasa di kota Padang.
Berdasarkan uraian sebelumnya maka dapat di buat hipotesis sebagai berikut :

$H_{1}$ : Pengetahuan Akuntansi

berpengaruh signifikan terhadap kinerja manajerial pada perusahaan manufaktur di provinsi sumbar.

\subsection{Pengaruh Kepribadian Wirausaha Terhadap Kinerja Manajerial \\ Menurut Stoner dan Edwart dalam} Winardi (2008) menjelaskan bahwa seorang manajer dapat disebut seorang wirausaha, apabila ia sanggup melaksanakan perubahan-perubahan yang bersifat inovatif dalam proses produksi yang di manajer olehnya. Seorang wirausaha pada situasi dan kondisi tertentu (apabila perusahaan kecil yang dibentuknya telah berkembang menjadi perusahaan besar) harus pula melaksanakan tugas-tugas seorang manajer dalam wujud melaksanakan fungsi-fungsi manajerial seperti perencanaan, pengorganisasian, memimpin dan mengawasi (Winardi, 2008).

Peneliti Siregar (2009) meneliti tentang pengaruh kepribadian wirausaha terhadap kinerja manajerial pada perusahaan jasa di kota medan. Hasil penelitian menunjukan bahwa kepribadian wirausaha tidak berpengaruh terhadap kinerja manajerial dalam suatu perusahaan. 
Pendapat tersebut sama dengan Ernawati (2011) yang meneliti tentang analisis kepribadian wirausaha terhadap kinerja manajerial pada perusahaan jasa di kota Medan pada perusahaan jasa. Hasil penelitian menunjukkan kepribadian wirausaha tidak berpengaruh terhadap kinerja manajerial. Sebelumnya Siregar dan Erlina (2007) juga meneliti tentang pengaruh kepribaian wirausaha terhadap kinerja manajerial pada perusahaan jasa di kota Medan. Hasil tersebut menunjukkan kepribadian wirausaha tidak memiliki pengaruh terhadap kinerja manajerial.

Sinta (2011) juga meneliti pengaruh kepribadian wirausaha terhadap kinerja manajerial pada PT Metro Pos. Hasil penelitian menunjukan bahwa kepribadian wirausaha berpengaruh terhadap kinerja manajerial. Pendapat ini sama dengan Nopalia, dkk (2012) yang meneliti tentang kepribadian wirausaha terhadap kinerja manajerial pada perusahaan dealer sepeda motor yang berpusat di kota Jambi. Hasil penelitianmenunjukan bahwa kepribadian wirausaha sangat berpengaruh terhadap kinerja manajerial dalam suatu perusahaan. Harisman (2012) telah meneliti tentang kepribadian wirausaha terhadap kinerja manajerial pada perusahaan jasa di kota Padang. Hasil tersebut juga menunjukkan pengaruh kepribadian wirausaha berpengaruh terhadap kinerja manajerial.

Berdasarkan uraian diatas, maka dapat dibuat hipotesis sebagai berikut :

$\mathrm{H}_{2}$ Kepribadian Wirausaha

Berpengaruh Signifikan Terhadap Kinerja Manajerial di Provinsi Sumatra Barat

\section{Rancangan penelitian dan Metodologi}

Populasi dalam penelitian ini adalah manajer perusahaan manufaktur di Provinsi Sumatra Barat. Pemilihan sampel dilakukan dengan metode Purposive Sampling dengan kriteria sebagai berikut

(i) perusahaan manufaktur yang memiliki karyawan minimal 22 orang, (ii) manajer yang memiliki latar belakang akuntansi, dan (iii) manajer yang memiliki pengalaman kerja minimal 2 tahun. Jenis data yang digunakan dalam penelitian ini adalah data primer.

Pengetahuan akuntansi ini diukur dengan 6 pertanyaan. Pertanyaan ini diadopsi dari instrumen yang dikembangkan oleh Spliker 1995, Bonner dan Walker 1994 (dalam Siregar, 2009). Variabel ini menggunakan tipe skala pengukuran dummy, setiap pertanyaan diberi beberapa pilihan jawaban tetapi hanya satu yang benar. Pemilihan jawaban 
yaitu, 1 untuk jawaban yang benar dan 0 untuk jawaban yang salah.

Kepribadian wirausaha merupakan keseluruhan cara seseorang untuk berinteraksi dan melihat peluang usaha. Pengukuran variabel ini menggunakan skala likert 1 sampai 7 yang diukur dengan 11 pertanyaan. Pertanyaan ini diadopsi dari instrumen yang dikembangkan oleh Steers dan Braunstein 1976 (dalam Siregar, 2009). Untuk sangat tidak setuju (1), tidak setuju (2), sedikit tidak setuju (3), netral (4), sedikit setuju (5), setuju (6) dan sangat setuju (7).

Kinerja manajerial merupakan ukuran seberapa efektif dan efesien manajer untuk mencapai tujuan organisasi. Pengukuran variabel ini menggunakan skala likert 1 sampai 7 yang diukur dengan 9 pertanyaan. Pertanyaan ini diadopsi dari instrumen yang dikembangkan oleh Mahoney 1965 (dalam Siregar, 2009). Untuk sangat tidak setuju (1), tidak setuju (2), sedikit tidak setuju (3), netral (4), sedikit setuju (5), setuju (6) dan sangat setuju (7).

Metode analisa yang digunakan adalah uji validitas, uji reabilitas, uji asumsu klasik ( uji normalitas, uji multikoliniearitas), uji f, dan uji t.

\section{Hasil dan Pembahasan}

\subsection{Statistik Deskriptif}

\section{Tabel 1}

\begin{tabular}{|l|c|c|c|c|c|}
\multicolumn{7}{|c|}{ Statistik Deskriptif } \\
\hline \multicolumn{1}{|c|}{ Variabel } & N & $\begin{array}{c}\text { Kisaran } \\
\text { Teoritis }\end{array}$ & $\begin{array}{c}\text { Kisaran } \\
\text { Aktual }\end{array}$ & Mean & $\begin{array}{c}\text { Standar } \\
\text { Deviasi }\end{array}$ \\
\hline Pengetahuan Akuntansi & 30 & $0-6$ & $3-6$ & 5,3800 & 0.7599 \\
\hline Kepribadian Wirausaha & 30 & $11-77$ & $39-73$ & 56,0667 & 6.3946 \\
\hline Kinerja Manajerial & 30 & $9-63$ & $46-61$ & 54,8887 & 3.3495 \\
\hline
\end{tabular}

Dari Tabel 1 dapat diketahui bahwa jumlah sampel yang diteliti adalah 30 responden. Berdasarkan kisaran teoritis variabel Pengetahuan Akuntasi memiliki nilai minimum 0 dan maximum 6 . Berdasarkan kisaran aktual jawaban responden memiliki nilai minimum 3 dan maximum 6 dari 6 item pertanyaan dengan rata-rata 5,38 dan standar deviasinya 0,76.

Berdasarkan kisaran teoritis variabel Kepribadian Wirausaha memiliki nilai minimum 11 dan maximum 77 . Berdasarkan kisaran aktual jawaban responden memiliki nilai minimum 39 dan maximum 73 dari 11 item pertanyaan dengan rata-rata 56,07 dan standar deviasinya 6,39.

Berdasarkan kisaran teoritis variabel Pengetahuan Akuntasi memiliki nilai minimum 9 dan maximum 63 Berdasarkan kisaran aktual jawaban responden memiliki nilai minimum 46 dan maximum 61 dari 9 item pertanyaan dengan rata-rata 54,89 dan standar deviasinya 3,34 . 


\subsection{Uji Validitas}

\section{Tabel 2}

Hasil Pengujian Validitas

\begin{tabular}{l|c|c|c|}
\hline \multicolumn{1}{|c|}{ Variabel } & KMO & Factor Loading & Keterangan \\
\hline Kepribadian Wirausaha &, 676 & $0,585-0,858$ & Valid \\
\hline Kinerja Manajerial &, 711 & $0,621-0,940$ & Valid \\
\hline
\end{tabular}

Dari tabel 2 di atas, untuk uji variabel pertama yaitu pengetahuan akuntansi dirancang dengan 6 pertanyaan pilihan ganda bukan dengan skala likert, variabel kedua yaitu kepribadian wirausaha dirancang dengan 11 item pertanyaan dan ternyata 5 petanyaan yang validsehinggaterdapat KMO sebesar 0,676 dengan faktor loding di atas 0,4, variabel ketiga yaitu Kinerja Manajerial dirancang dengan 9 pertanyaan dan ternyata 4 pertanyaan yang valid sehingga memiliki KMO sebesar 0,711 dengan factor loading di atas 0,4. Hal ini menunjukkan bahwa variabel-variabel tersebut valid untuk di uji.

\subsection{Uji Reliabilitas}

\section{Tabel 3}

Hasil Uji Reliabilitas

\begin{tabular}{|l|c|c|}
\hline \multicolumn{1}{|c|}{ Variabel } & Cronbach's Alpha & Keterangan \\
\hline Kepribadian Wirausaha & 0,668 & Reliabel \\
\hline Kineja Manajerial & 0,839 & Reliabel \\
\hline
\end{tabular}

Dari tabel 3 di atas, untuk uji dari variabel pertama yaitu pengetahuan akutansi di ukur pentanyaan pilihan ganda bukan skala likert, variabel kedua yaitu kepribadian wirausaha memiliki Cronbach's Alpha 0,668, dan variabel ketiga yaitu kinerja manajerial memiliki Cronbach's Alpha 0,839. Hasil menunjukkan bahwa semua variabel reliabel karena memiliki Cronbach's Alpha di atas 0,06.

\subsection{Uji Normalitas}

Tabel 4

Uji Normalitas

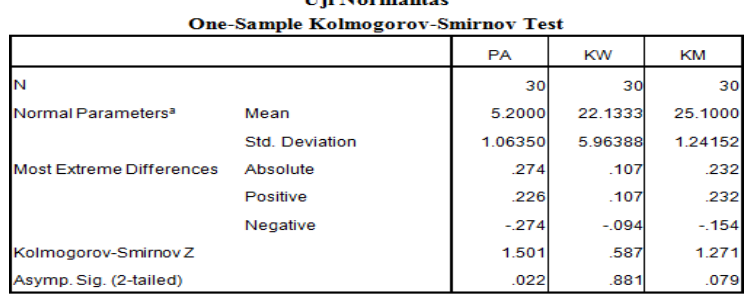

a. Test distribution is Normal

Berdasarkan tabel 4 KolmogorovSmirnov Test menyimpulkan sebagai berikut:

a. Nilai signifikan variabel PA 0,022 $<0,05$ maka distribusi data variabel PA tidak normal, karena variabel dummy.

b. Nilai signifikan variabel $\mathrm{KW}$ 0,881>0,05 maka distribusi data variabel $\mathrm{KW}$ normal.

c. Nilai signifikan variabel KM 0,079>0,05 maka distribusi data variabel KM normal. 


\subsection{Uji Multikoliniearitas}

Tabel 5

Hasil uji Multikoliniearitas

\begin{tabular}{|c|r|r|l|}
\hline \multirow{2}{*}{ Variabel } & \multicolumn{2}{|c|}{ Collinearity Statistics } & \multirow{2}{*}{ Keterangan } \\
\cline { 2 - 3 } & Tolerance & \multicolumn{1}{c|}{ VIF } & \\
\hline Pengetahuan Akuntansi &, 990 & 1,011 & $\begin{array}{l}\text { Tidak Terjadi } \\
\text { Multikoliniearitas }\end{array}$ \\
Kepribadian Wirausaha &, 990 & 1,011 & $\begin{array}{l}\text { Tidak Terjadi } \\
\text { Multikoliniearitas }\end{array}$ \\
\hline
\end{tabular}

Dari hasil analisis tabel 5 terdapat dua variabel bebas (independen) dalam penelitian ini nilai VIF-nya di bawah 10 dan tolerance mendekati 1 . Ini berarti tidak terjadi Multikoliniearitas antara variabel bebas tersebut. Dengan demikian dapat disipulkan bahwa variabel-variabel bebas (independen) berupa pengetahuan akuntansi dan kepribadian wirausaha tersebut memenuhi persyaratan asumsi klasik tentang multikoliniearitas.

\subsection{Regresi Linier Berganda}

Tabel 6

Hasil pengujian

Coefficients $^{a}$

\begin{tabular}{|rl|r|r|c|}
\hline \multirow{2}{*}{} & \multirow{2}{*}{ Model } & \multicolumn{2}{|c|}{$\begin{array}{c}\text { Unstandardized } \\
\text { Coefficients }\end{array}$} & $\begin{array}{c}\text { Standardized } \\
\text { Coefficients }\end{array}$ \\
\cline { 3 - 5 } & \multicolumn{1}{|c|}{ B } & \multicolumn{1}{c|}{$\begin{array}{c}\text { Std. } \\
\text { Error }\end{array}$} & Beta \\
\hline 1 & (Constan) & 28,371 & 1,342 & \\
& PA &,- 601 &, 194 &,- 515 \\
& KW &,- 006 &, 035 &,- 031 \\
\hline
\end{tabular}

a Dependent Variable: KM

Berdasarkan tabel 6 pada kolom Unstandardized Coefficients bagian B diperoleh model persamaan, regresi linier berganda sebagai berikut:

$$
Y=28,371-0,601_{X 1}-0,006_{X 2}
$$

\subsection{Uji F}

Tabel 7

\begin{tabular}{|c|c|c|c|c|c|c|}
\hline \multicolumn{7}{|c|}{$\begin{array}{l}\text { Hasil Uji F } \\
\text { ANOVA }^{b}\end{array}$} \\
\hline & Model & $\begin{array}{l}\text { Sum of } \\
\text { Squares }\end{array}$ & Df & $\begin{array}{c}\text { Mean } \\
\text { Square }\end{array}$ & $\mathrm{F}$ & Sig. \\
\hline 1 & $\begin{array}{l}\text { Regression } \\
\text { Residual } \\
\text { Total }\end{array}$ & $\begin{array}{l}11,755 \\
32,945 \\
44,700\end{array}$ & $\begin{array}{r}2 \\
27 \\
29\end{array}$ & $\begin{array}{l}5,878 \\
1,220\end{array}$ & 4,817 &, $016^{\mathrm{a}}$ \\
\hline
\end{tabular}

Dari tabel terlihat nilai $\mathrm{F}$ hitung yang diperoleh sebesar 4,817 dengan nilai signifikan 0,016 didalam pengujian hipotesis digunakan tingkat alpha sebesar 0,05. Hasil yang diperoleh memperlihatkan bahwa nilai signifikan sebesar $0,016<$ alpha 0,05. Maka keputusannya adalah pengetahuan akuntansi dan kepribadian wirausaha berpengaruh terhadap kinerja manajerial.

\subsection{Uji t}

Tabel 8

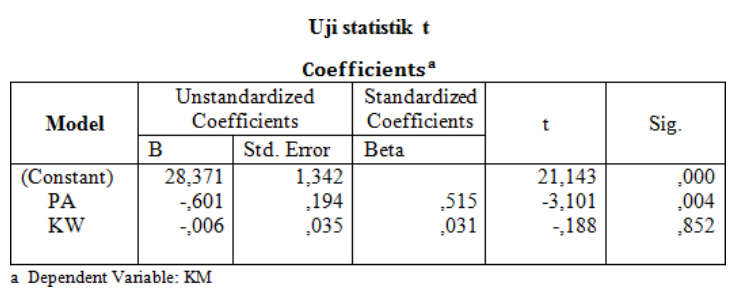

Hasil pengujian statistik $\mathrm{t}$ pada tabel 4.12 Dapat dijelasan sebagai berkut:

\section{Pengaruh pengetahuan akuntansi terhadap kinerja manajerial.}

Berasarkan hasil pengujian hipotesis pertama untuk menguji pengetahuan akuntansi terhadap kinerja 
manajerial diperoleh koefesien sebesar 0,601 didalam proses pengujian diperoleh nilai signifikan sebesar 0,004. Di dalam tahapan pegolahan data digunakan tingkat alpha sebesar 0,05. Hasil yang diperoleh $0,004<$ alpha 0,05. Keputusannya adalah (H1) diterima sehingga dapat disimpulkan bahwa pengetahuan akuntansi berpengaruh terhadap kinerja manajerial. Hasil penelitian ini sama dengan penelitian Siregar (2009) meneliti tentang pengaruh pengetahuan akuntansi terhadap kinerja manajerial pada perusahaan jasa di kota medan. Hasil penelitian menunjukan bahwa pengetahuan akuntansi sangat berpengaruh terhadap kinerja manajerial dalam suatu perusahaan.

Ernawati (2011) meneliti tentang analisis pengetahuan akuntansi terhadap kinerja manajerial pada perusahaan jasa. Hasil menunjukan bahwa pengetahuan akuntansi berpengaruh terhadap kinerja manajerial. Sinta (2011) juga meneliti tentang pengaruh pengetahuan akuntansi terhadap kinerja manajerial pada PT Metro Pos, hasil menunjukan bahwa pengetahuan akuntansi berpengaruh terhadap kinerja menajerial.

Pengujian terhadap pengaruh pengetahuan akuntansi terhadap kinerja manajerial juga pernah dilakukan oleh Siregar (2013) yang meneliti tentang pengaruh pengetahuan akuntansi terhadap kinerja manajerial pada usaha kecil menengah di Kabupaten Sleman Yogyakarta. Hasil penelitian tersebut menyatakan pengetahuan akuntansi berpengaruh terhadap kinerja manajerial pada usaha kecil menengah. Sebelumnya Siregar dan Erlina (2007) juga telah meneliti tentang pengaruh pengetahuan akuntansi terhadap kinerja manajerial pada perusahaan jasa di kota Medan. Hasil tersebut menunjukkan pengetahuan akuntansi berpengaruh terhadap kinerja manajerial pada perusahaan jasa di kota Medan.

Pendapat tersebut berbeda dengan Harisman (2012) yang meneliti tentang pengaruh pengetahuan akuntansi terhadap kinera manajerial pada perusahaan jasa di kota Padang. Hasil penelitian tersebut menunjukkan pengetahuan akuntansi tidak berpengaruh terhadap kinerja manajerial pada perusahaan jasa di kota Padang.

2. Pengaruh kepribadian wirausaha terhadap kinrja manajerial.

Berasarkan hasil pengujian hipotesis kedua untuk menguji kepribadian wirasaha terhadap kinerja manajerial diperoleh koefesien sebesar -0,006 didalam proses pengujian diperoleh nilai signifikan sebesar 0,852. Di dalam tahapan pegolahan data digunakan tingkat alpha sebesar 0,05. Hasil yang diperoleh 0,852>alpha 0,05. Keputusannya adalah 
(H2) ditolak sehingga dapat disimpulkan bahwa kepribadian wirausahatidak berpengaruh terhadap kinerja manajerial.

Hasil penelitian ini sama dengan peneliti Siregar (2009) meneliti tentang pengaruh kepribadian wirausaha terhadap kinerja manajerial pada perusahaan jasa di kota Medan. Hasil penelitian menunjukan bahwa kepribadian wirausaha tidak berpengaruh terhadap kinerja manajerial dalam suatu perusahaan.

Pendapat tersebut sama dengan Ernawati (2011) yang meneliti tentang analisis kepribadian wirausaha terhadap kinerja manajerial pada perusahaan jasa di kota Medan pada perusahaan jasa. Hasil penelitian menunjukkan kepribadian wirausaha tidak berpengaruh terhadap kinerja manajerial. Sebelumnya Siregar dan Erlina (2007) juga meneliti tentang pengaruh kepribaian wirausaha terhadap kinerja manajerial pada perusahaan jasa di kota Medan. Hasil tersebut menunjukkan kepribadian wirausaha tidak memiliki pengaruh terhadap kinera manajerial.

Tetapi berbeda dengan Sinta (2011) juga meneliti tentang pengaruh kepribadian wirausaha terhadap kinerja manajerial pada PT Metro Pos. Hasil penelitian menunjukan bahwa kepribadian wirausaha berpengaruh terhadap kinerja manajerial. Pendapat ini juga sama dengan Nopalia, dkk (2012) yang meneliti tentang kepribadian wirausaha terhadap kinerja manajerial pada perusahaan dealer sepeda motor yang berpusat di kota Jambi. Hasil penelitianmenunjukan bahwa kepribadian wirausaha sangat berpengaruh terhadap kinerja manajerial dalam suatu perusahaan. Harisman (2012) telah meneliti tentang kepribadian wirausaha terhadap kinerja manajerial pada perusahaan jasa di kota Padang. Hasil tersebut juga menunjukkan pengaruh kepribadian wirausaha berpengaruh terhadap kinerja manajerial.

\section{Kesimpulan}

Berdasarkan analisis dan pembahasan hasil pengujian hipotesis maka diajukan beberapa kesimpulan penting yang merupakan jawaban dari sejumlah masalah yang diajukan di dalam penelitian ini yaitu

1. Pengetahuan akuntansi berpengaruh signifikan terhadap kinerja manajerial.

2. Kepribadian wirausaha tidak berpengaruh signifikan terhadap kinerja manajerial

3. Pengujian secara simultan (bersama-sama), hasil penelitian ini menunjukkan bahwa secara signifikan seluruh variabel bebas yang terdiri dari pengetahuan akuntansi dan kepribadian 
wirausaha berpengaruh terhadap kinerja manajerial pada perusahaan manufaktur di Provinsi Sumatera Barat. Hal ini mengindikasikan bahwa $\mathrm{H}_{0}$ ditolak dan $\mathrm{H}_{\mathrm{a}}$ sebagai hipotesis alternatif diterima.

\section{DAFTAR PUSTAKA}

Ernawati, Lies. 2011. Analisis Pegetahuan Akuntansi dan Kepribadian Wirausaha terhadap Kinerja Manajerial pada Perusahaan Jasa. Jurnal Ekonomika Vol.4 No.2 Desember.

Harisman, Dody. 2012. Pengaruh Pengetahuan Akuntansi dan Kepribadian Wirausaha Terhadap Kinerja Manajerial Pada Perusahaan Jasa di Kota Padang. Skripsi. Universitas Bunghatta. Padang

Hudayanti, Ataina. 2002. Perkembangan Penelitian Akuntansi Keprilakuan : Berbagai Teori dan Pendekatan Yang Melandasi. JAAI Volume 6 No.2 Desember

Nopalia, dkk. 2012. Pengaruh Pengguna Informasi Akuntansi Manajemen dan Kepribadian Wirausaha Terhadap Kinerja Manajerial.eJurnal Binar Akuntansi Vo.. 1 No. 1 September

Sabri. 2013. Kewirausahaan (Entrepreneurship) : Modal Manusia Dalam Membangun Perekonomian.Jurnal Ekonomika Universitas Almuslim Bireuen Vol.IV No. 7. Maret 2013

Sinta, Dewi. 2011. Pengaruh pengetahuan Akuntansi dan Kepribadian
Kewirausahaan Terhadap kinerja Manajerial (Studi pada PT Metro Pos). Skripsi. Universitas Persada Indonesia Y.A.I. Jakarta

Siregar, Aditya Fitri. 2009. Pengaruh Pengetahuan Akuntansi dan Kepribadian Wirausaha Terhadap Kinerja Manajerial Pada Perusahaan Jasa di Kota Medan. Skripsi. Universitas Sumatra Utara. Medan

Siregar, Aditya Fitri dan Erlina. 2007. Pengaruh Pengetahuan Akuntansi dan Kepribadian Wirausaha Terhadap Kinerja Manajerial Pada Perusahaan Jasa di Kota Medan. Universitas Sumatra Utara. Medan

Siregar, Resa Kurnia. 2013. Pengaruh Pengetahuan Akuntansi, Kepribadian Wirausaha dan Ketidakpastian Lingkungan Terhadap Kinerja manajer Pada Usaha Kecil Menengah (UKM) Di Kabupaten Sleman Yogyakarta. Tesis. UPN Veteran. Yogyakarta

Adam, Tim and Goyal, Vidhan K. 2003. The Investment Opportunity Set and its Proxy Variabels: Theory and Evidence. Hong Kong University of Science and Technology.

Analisa, Yangs. 2011. Pengaruh Ukuran Perusahaan, Leverage dan Profitabilitas Terhadap Nilai Perusahaan. Skripsi. Fakultas Ekonomika dan Bisnis. Universitas Diponegoro. Semarang. 